\title{
Ventilatory Response to Carbon Dioxide in Newborn Infants
}

\author{
ALFRED N. KRAUSS, DAVID B. KLAIN, STEPHANIE WALDMAN, AND PETER A. M. AULD ${ }^{(18)}$ \\ Division of Newborn Medicine, Department of Pediatrics, New York Hospital-Cornell University \\ Medical Center, New York, New York, USA
}

\section{Extract}

In order to determine whether the mechanical characteristics of the lungs of newborn infants imposed limitations on their ventilatory response to carbon dioxide, 11 premature and 5 full term infants ranging in gestational ages from 28-40 weeks and in birth weights from 964 to $4,040 \mathrm{~g}$ were studied by a rebreathing technique. Sensitivity to carbon dioxide determined by this method revealed a good correlation with compliance $(\mathrm{r}=0.6, P<0.001)$, and an even stronger correlation with gestational age $(\mathrm{r}=0.84, P<0.001)$. Because compliance also improved with increasing postconceptional age, the current study does not permit one to differentiate between neurologic or pulmonary mechanical factors which may affect ventilatory response to carbon dioxide.

\section{Speculation}

Infants who respond to carbon dioxide with an increase in minute ventilation should also increase their rate of pulmonary work. Failure of this work rate to increase in response to elevated carbon dioxide tensions may indicate that nonresponsive infants are already working at their maximum level of pulmonary work, and would thus permit differentiation of infants who have mechanical limitations to increased performance as opposed to those who lack chemoreflexes.

Apneic spells of greater than $15-20 \mathrm{sec}$ duration are a frequent occurrence in infants of low birth weight (9). During these spells, oxygen tension falls, $\mathrm{pH}$ drops, and carbon dioxide tension rises. The presence of apnea under these conditions suggests either an absence of the reflexes which are normally sensitive to these modalities, or an inability of the lungs and muscles of respiration to increase ventilation because of mechanical limitations. Previous studies from this and other laboratories $(8,12)$ have demonstrated the presence of chemoreceptors to oxygen in all infants, including those of very low birth weights. Newborn infants also are capable of forming a cerebrospinal fluid of appropriate $\mathrm{pH}$ in order to maintain a normal respiratory compensation (7). Term and premature infants are able to increase their ventilation $\left(\dot{\mathrm{V}}_{\mathrm{E}}\right)$ in response to increased tensions of carbon dioxide $(1,2,4)$. However, it is believed by some that their response to $\mathrm{CO}_{2}$ is diminished compared with adults because of an inability to maintain a normal $\mathrm{CO}_{2}$ during stimulation of respiration with $\mathrm{CO}_{2}$ (13). The present study was undertaken to determine whether a limitation of ventilatory response to $\mathrm{CO}_{2}$ exists in the premature infant, and whether mechanical factors could account for the changes in the ventilatory response to $\mathrm{CO}_{2}$ observed during the neonatal period.

\section{METHODS}

Sixteen infants, all of appropriate birth weight for gestational age, were the subjects of this study. Eleven (cases 1-11) were premature and ranged in birth weight from $964-1,700 \mathrm{~g}$ and in gestational age from 28-36 weeks. Five (cases 12-16) were born at term (approximately 40 weeks), and ranged in birth weight from 2,480-4,040 g. None were ill. All were studied with the knowledge and consent of their parents.

The maturity of infants is described in three ways. Postnatal age refers only to age after birth. Gestational age refers to age from conception to the time of birth, and is used only in connection with infants under 1 week of age. Postconceptional age refers to total age after conception, and includes both intrauterine and extrauterine maturation.

Serial studies were carried out on all premature infants beginning during the first week of life when possible, and at approximately weekly intervals thereafter. All infants were studied within $60 \mathrm{~min}$ of feeding. Environmental temperatures were maintained at $34-36^{\circ}$ by the use of heat lamp or, in the case of the smaller infants, by incubator.

Functional residual capacity (FRC) was measured by the helium dilution method of Krauss and Auld (6). Total pulmonary compliance was calculated from simultaneous tracings of intraesophageal pressure, obtained with a pressure

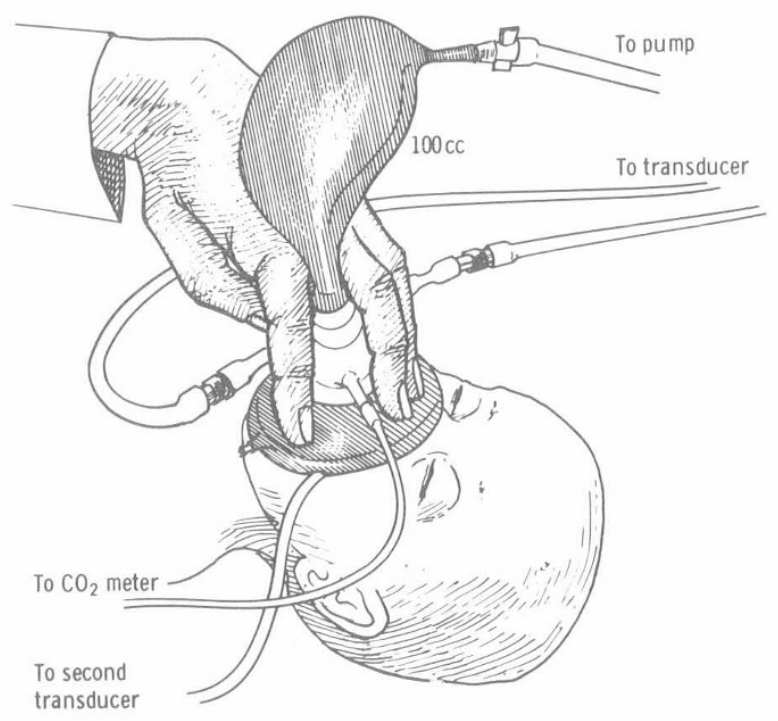

Fig. 1. Rebreathing and sampling apparatus used in the present study. 


\begin{tabular}{|c|c|c|c|c|c|c|c|c|c|c|c|c|c|c|c|c|c|c|}
\hline Case & $\begin{array}{c}\text { Gesta- } \\
\text { tional } \\
\text { age, wk }\end{array}$ & $\begin{array}{l}\text { Study } \\
\text { age, } \\
\text { days }\end{array}$ & $\begin{array}{l}\text { Birth } \\
\text { wt, g }\end{array}$ & $\begin{array}{l}\text { Study } \\
\text { wt, g }\end{array}$ & $\begin{array}{l}\text { Study } \\
\text { length, } \\
\mathrm{cm}\end{array}$ & $\begin{array}{c}\text { Body } \\
\text { surface } \\
\text { area, } \mathrm{m}^{2}\end{array}$ & $\begin{array}{c}\mathrm{FRC}, \\
\mathrm{cc}\end{array}$ & $\begin{array}{l}\text { FRC, } \\
\mathrm{cc} / \mathrm{cm}\end{array}$ & $\begin{array}{c}\text { Compliance, } \\
\mathrm{ml} / \mathrm{cm} \\
\mathrm{H}_{2} \mathrm{O}\end{array}$ & $\begin{array}{c}\text { Compli- } \\
\text { ance/FRC, } \\
\mathrm{ml} / \mathrm{cm} \\
\mathrm{H}_{2} \mathrm{O} / \mathrm{cc}\end{array}$ & $\begin{array}{l}\text { Total } \\
\text { pulmonary } \\
\text { resistance }\end{array}$ & $\begin{array}{c}\text { Baseline } \\
\mathrm{V}_{\mathrm{E}} \\
\mathrm{ml} / \mathrm{min}\end{array}$ & $\begin{array}{c}\Delta \mathrm{V}_{\mathrm{E}} \\
\mathrm{P}_{\mathrm{CO}_{2}} \\
\mathrm{ml} / \mathrm{mm} \\
\mathrm{Hg}\end{array}$ & $\begin{array}{c}\Delta \dot{\mathrm{V}}_{\mathrm{E}} / \mathrm{FRC} / \\
\mathrm{PCO}_{2} \\
\mathrm{ml} / \mathrm{cc} / \mathrm{mm} \\
\mathrm{Hg}\end{array}$ & $\begin{array}{c}\text { Frequency } \\
\text { in } \\
\text { room air }\end{array}$ & $\Delta \mathrm{f} / \Delta \mathrm{P}_{\mathrm{CO}_{2}}$ & $\begin{array}{c}\mathrm{V}_{\mathrm{T}} \text { in } \\
\text { room air, } \\
\mathrm{cc}\end{array}$ & $\begin{array}{l}\Delta \mathrm{V}_{\mathrm{T}} / \\
\Delta \mathrm{P}_{\mathrm{CO}_{2}}, \\
\mathrm{ml} / \mathrm{mm} \\
\mathrm{Hg}\end{array}$ \\
\hline \multirow[t]{2}{*}{1} & 28 & 53 & 964 & 1,790 & 46 & 0.205 & 66 & 1.43 & 1.26 & 0.019 & 112 & 1,376 & 57 & 1 & 74 & -.6 & 18.6 & 1.1 \\
\hline & & 60 & & 2,080 & 46 & 0.273 & 65 & 1.41 & 2.36 & 0.036 & 84 & 1,393 & 118 & 2 & 86 & -1.2 & 16.2 & 1.8 \\
\hline \multirow[t]{4}{*}{2} & 30 & 1 & 1,300 & 1,300 & 38 & 0.169 & 33 & 0.87 & 1.77 & 0.054 & 52 & 864 & 8 & 0.2 & 96 & .9 & 9.0 & 0 \\
\hline & & 10 & & 1,250 & 39 & 0.167 & 41 & 1.03 & 1.59 & 0.039 & 108 & 1,210 & 246 & 6 & 72 & 3.8 & 16.8 & 2.4 \\
\hline & & 17 & & 1,380 & 40 & 0.183 & 44 & 1.09 & 1.02 & 0.023 & 97 & 1,057 & 59 & 1 & 85 & -2.1 & 12.4 & 1.2 \\
\hline & & 34 & & 1,710 & 43 & 0.225 & 41 & 0.95 & 1.50 & 0.037 & 65 & 1,601 & 354 & 9 & 88 & 4.5 & 18.2 & 2.5 \\
\hline \multirow[t]{4}{*}{3} & 30 & 1 & 1,300 & 1,300 & 40 & 0.175 & 41 & 1.03 & 1.98 & 0.048 & 155 & 620 & -21 & -0.4 & 56 & -8.8 & 11.0 & 1.6 \\
\hline & & 9 & & 1,230 & 41 & 0.171 & 69 & 1.68 & 1.58 & 0.023 & 107 & 1,006 & -65 & -1 & 85 & -8.9 & 11.8 & 1.8 \\
\hline & & 37 & & 1,650 & 41 & 0.212 & 69 & 1.68 & 1.57 & 0.023 & 98 & 1,719 & 496 & 7 & 90 & 2.3 & 19.0 & 4.7 \\
\hline & & 50 & & 2,130 & 45 & 0.273 & 75 & 1.67 & 6.42 & 0.086 & & 2,290 & 753 & 10 & 68 & 5.0 & 33.9 & 6.4 \\
\hline \multirow[t]{4}{*}{4} & 28 & 10 & 1,006 & 1,100 & 39 & 0.152 & 26 & 0.67 & 0.74 & 0.028 & 121 & 582 & 33 & 1 & 87 & -3.5 & 6.7 & 0.5 \\
\hline & & 20 & & 1,130 & 40 & 0.158 & 62 & 1.55 & 0.88 & 0.014 & 159 & 994 & 6 & 0.1 & 78 & -4.0 & 12.6 & 1.3 \\
\hline & & 35 & & 1,430 & 40 & 0.188 & 33 & 0.83 & 1.54 & 0.047 & 98 & 1,783 & 80 & 2 & 123 & -5.0 & 14.3 & 3.3 \\
\hline & & 50 & & 2,050 & 45 & 0.266 & 45 & 1.00 & 0.74 & 0.016 & 236 & 1,189 & 182 & 4 & 55 & -3.8 & 21.5 & 3.5 \\
\hline \multirow[t]{2}{*}{5} & 29 & 2 & 1,180 & 1,190 & 35 & 0.149 & 11 & 0.31 & 1.36 & 0.124 & 219 & 748 & -10 & -1 & 87 & -.5 & 8.6 & -0.1 \\
\hline & & 11 & & 1,070 & 36 & 0.141 & 21 & 0.58 & 0.46 & 0.220 & 297 & 703 & 55 & 3 & 58 & -.5 & 11.8 & 0.7 \\
\hline \multirow[t]{3}{*}{6} & 28 & 1 & 1,020 & 1,049 & 38 & 0.145 & 56 & 1.47 & 2.13 & 0.038 & 190 & 428 & 28 & 0.7 & 41 & 0 & 10.8 & 0.8 \\
\hline & & 15 & & 990 & 39 & 0.141 & 26 & 0.67 & 1.10 & 0.042 & 116 & 387 & 79 & 3 & 51 & 0 & 7.4 & 1.7 \\
\hline & & 49 & & 1,230 & 41 & 0.171 & 51 & 1.24 & 1.70 & 0.033 & 177 & 1,157 & 349 & 7 & 60 & 3.4 & 19.3 & 4.3 \\
\hline \multirow[t]{2}{*}{7} & 34 & 1 & 1,920 & 1,920 & 44 & 0.249 & 42 & 0.95 & 2.22 & 0.053 & 59 & 1,061 & 149 & 4 & 87 & -.4 & 12.2 & 1.5 \\
\hline & & 9 & & 1,860 & 44 & 0.243 & 56 & 1.27 & 1.82 & 0.033 & 47 & 988 & 102 & 2 & 68 & -2.3 & 14.5 & 2.0 \\
\hline \multirow[t]{3}{*}{8} & 34 & 5 & 1,700 & 1,560 & 43 & 0.211 & 41 & 0.95 & 2.16 & 0.053 & 106 & 995 & 155 & 3 & 60 & 3.7 & 16.6 & 0.6 \\
\hline & & 12 & & 1,620 & 44 & 0.220 & 59 & 1.34 & 2.29 & 0.039 & 112 & 765 & 140 & 2 & 42 & 0.9 & 18.0 & 1.8 \\
\hline & & 26 & & 1,900 & 45 & 0.251 & 67 & 1.49 & 1.28 & 0.019 & 98 & 1,522 & 231 & 4 & 67 & 4.3 & 22.7 & 1.2 \\
\hline \multirow[t]{3}{*}{9} & 36 & 1 & 1,580 & 1,580 & 43 & 0.213 & 37 & 0.84 & 4.35 & 0.118 & 23 & 378 & 108 & 3 & & 0.5 & & 1.3 \\
\hline & & 10 & & 1,600 & 44 & 0.218 & 42 & 0.95 & 1.57 & 0.038 & 144 & 752 & 55 & 1 & 62 & -.4 & 12.0 & 1.2 \\
\hline & & 18 & & 1,890 & 45 & 0.250 & 58 & 1.29 & 2.63 & 0.045 & & 938 & 49 & 0.8 & 61 & -1.0 & 15.3 & 1.0 \\
\hline \multirow[t]{3}{*}{10} & 35 & 2 & 1,580 & 1,615 & 41 & 0.209 & 54 & 1.32 & 1.66 & 0.031 & 99 & 983 & 21 & 0.3 & 68 & 1.9 & 14.5 & -0.1 \\
\hline & & 10 & & 1,600 & 42 & 0.211 & 56 & 1.33 & 2.10 & 0.038 & 81 & 950 & 109 & 2 & 50 & -.2 & 18.7 & 2.1 \\
\hline & & 21 & & 1,960 & 44 & 0.253 & 78 & 1.77 & 2.02 & 0.026 & 63 & 1,204 & 209 & 3 & 56 & 2.1 & 21.5 & 2.3 \\
\hline \multirow[t]{3}{*}{11} & 36 & 1 & 1,660 & 1,660 & 42 & 0.217 & 55 & 1.31 & 1.53 & 0.028 & 40 & 654 & 123 & 2 & 83 & 1.7 & 7.9 & 1.4 \\
\hline & & 9 & & 1,580 & 44 & 0.216 & 53 & 1.20 & 2.14 & 0.040 & 75 & 785 & 171 & 3 & 41 & -.2 & 19.1 & 3.3 \\
\hline & & 29 & & 2,200 & 47 & 0.288 & 66 & 1.40 & 2.85 & 0.043 & & 1,597 & 415 & 6 & 50 & -1.3 & 32.3 & 6.8 \\
\hline 12 & 40 & 4 & 2,520 & 2,450 & 45 & 0.302 & 112 & 2.49 & 7.12 & 0.064 & 32 & 1,669 & 469 & 4 & 78 & 2.4 & 21.4 & 5.0 \\
\hline 13 & 40 & 2 & 3,200 & 3,020 & 51 & 0.385 & 71 & 1.39 & 3.46 & 0.049 & 74 & 1,306 & 479 & 7 & 52 & 6.1 & 25.4 & 5.5 \\
\hline 14 & 40 & 10 & 2,750 & 2,480 & 48 & 0.319 & 42 & 0.88 & 2.73 & 0.065 & 54 & 992 & 268 & 6 & 47 & 1.5 & 20.6 & 4.4 \\
\hline 15 & 40 & 3 & 4,180 & 4,040 & 51 & 0.476 & 95 & 1.86 & 5.59 & 0.059 & 125 & 1,432 & 187 & 4 & 70 & 2.0 & 20.8 & 2.5 \\
\hline 16 & 40 & 1 & 3,250 & 3,150 & 46 & 0.188 & 87 & 1.89 & 3.87 & 0.044 & 52 & 1,854 & 400 & 2 & 71 & 4.0 & 26.0 & 4.6 \\
\hline
\end{tabular}

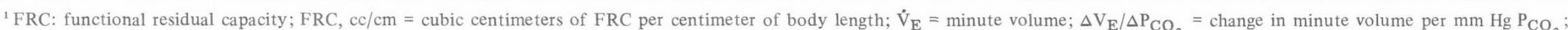

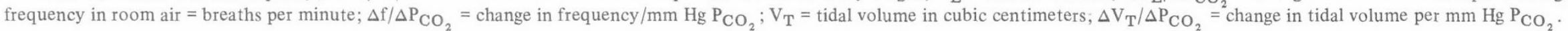


transducer attached to a water-filled, open-ended polyethylene feeding tube, and tidal volume, obtained with a pediatric wedge spirometer. Total pulmonary resistance was calculated from simultaneous tracings of intraesophageal pressure and respiratory flow using the same apparatus. The infant breathed into the spirometer through a rubber-rimmed face mask covering both nose and mouth. The mask was attached to the spirometer with stiff polyethylene tubing with no measurable resistance. Recordings were made on a 4-channel polygraph (14). Calculations of resistance and compliance were made from tracings of $6-10$ breaths during quiet spontaneous respiration according to the method of Cook and colleagues (3). Volume was calibrated using a syringe of known volume. Pressure was calibrated with a water-filled manometer. Flow was calibrated electronically.

Ventilatory response was determined by the method of Read (11), allowing the patient to rebreathe $40 \%$ oxygen and $5 \%$ carbon dioxide in a bag with a volume approximately equal to that of the patient's FRC. Tidal volume was measured with a pneumotachygraph mask with a resistance of $1.0 \mathrm{~cm}$ $\mathrm{H}_{2} \mathrm{O} /$ liter/sec (Fig. 1). Flow through this mask was electronically integrated to give volume. Gas was sampled from the mask at the infant's nose and recirculated via an infrared $\mathrm{CO}_{2}$ meter (15). The polygraph was used to obtain a simultaneous tracing of tidal volume and end-tidal carbon dioxide. The carbon dioxide built up at a rate of $1-1.5 \% / \mathrm{min}$. Leaks were manifest as an acute fall in the continuous $\mathrm{CO}_{2}$ tracing; when this occurred the run was abandoned. Using the method of least squares tidal volume, respiratory frequency (f), and minute volume $\left(\dot{V}_{E}\right)$ were plotted against end-tidal $\mathrm{CO}_{2}$. Four or five points obtained at 30 -sec intervals were obtained for the construction of each plot. The slope of the plot, $\Delta \dot{\mathrm{V}}_{\mathrm{E}} / \mathrm{P}_{\mathrm{CO}_{2}}$, represents the $\mathrm{CO}_{2}$ sensitivity. All data are presented in Table 1. In addition, the data was analyzed in respect to body weight (in kilograms) and FRC to determine the effect of infant size.

\section{- RESUlts}

A significant correlation between $\mathrm{CO}_{2}$ sensitivity and compliance $(\mathrm{r}=0.60, P<0.001)$ was found when all data were pooled. No correlations between specific compliance $(\mathrm{r}=$ $0.005)$ and total pulmonary resistance $(\mathrm{r}=0.37)$ and $\mathrm{CO}_{2}$ sensitivity were found.

When data from individual infants were examined, the correlations between $\mathrm{CO}_{2}$ sensitivity and compliance were less apparent. Some infants showed increases in $\mathrm{CO}_{2}$ sensitivity despite little or no change in the mechanical characteristics of their lungs (cases 2, 4, 6, 8, and 10). This led to an examination of the relation between $\mathrm{CO}_{2}$ sensitivity and age. In general, increased $\mathrm{CO}_{2}$ sensitivity was seen with both increasing postnatal age (Fig. 2) and postconceptional age (Fig. 3). Infants studied after 37 weeks' postconceptional age had 6 times the $\mathrm{CO}_{2}$ sensitivity of infants studied at less than 33 weeks' postconceptional age $(262 \mathrm{cc} / \mathrm{min} / \mathrm{mm} \mathrm{Hg}$ versus 38 $\mathrm{cc} / \mathrm{min} / \mathrm{mm} \mathrm{Hg}, P<0.005)$. These differences are listed in Table 2, along with data sized by body weight and FRC.

In order to separate the effects of extrauterine development from intrauterine maturation, all infants studied at under 1 week of postnatal age were compared after being separated into groups by gestational age. $\mathrm{CO}_{2}$ sensitivity showed a highly significant correlation with gestational age $(\mathrm{r}=0.84, P<$ $0.001)$. These data are presented in Figure 4.

When change in minute volume per kilogram of body weight or per cubic centimeter of $\mathrm{FRC}$ was plotted against $\mathrm{P}_{\mathrm{CO}_{2}}$, less mature infants continued to show a significantly diminished response to $\mathrm{CO}_{2}$ than more mature infants (Figs. 5-7). Correlations with various physical and maturational variables are listed in Table 3.

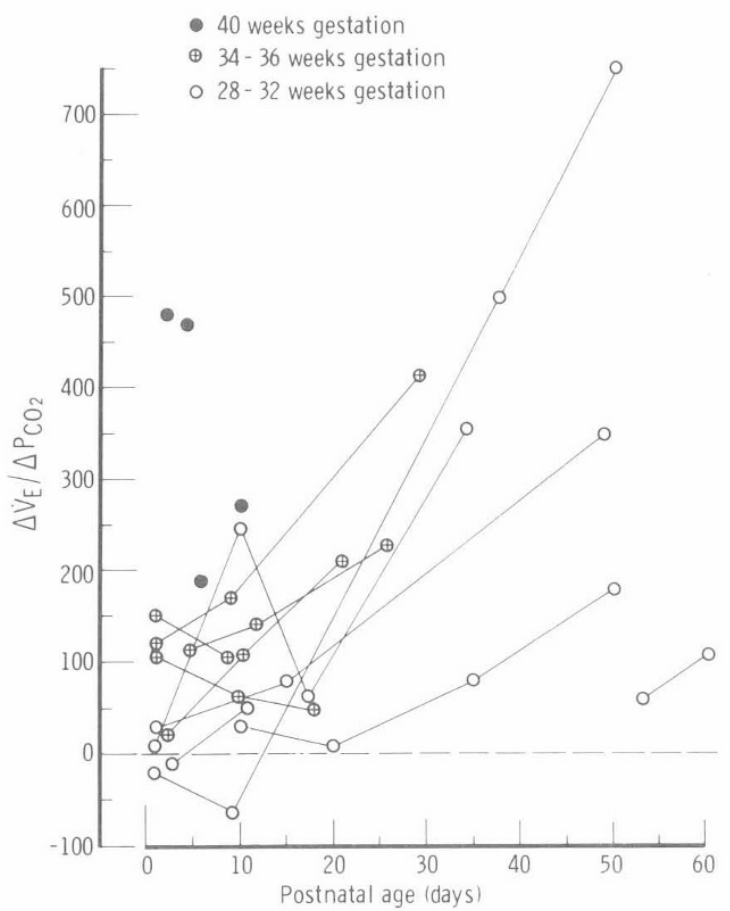

Fig. 2. Ventilatory response to carbon dioxide $\left(\Delta \dot{\mathrm{V}}_{\mathrm{E}} / \mathrm{P}_{\mathrm{CO}_{2}}\right)$ versus postnatal age in days in infants of differing maturity.

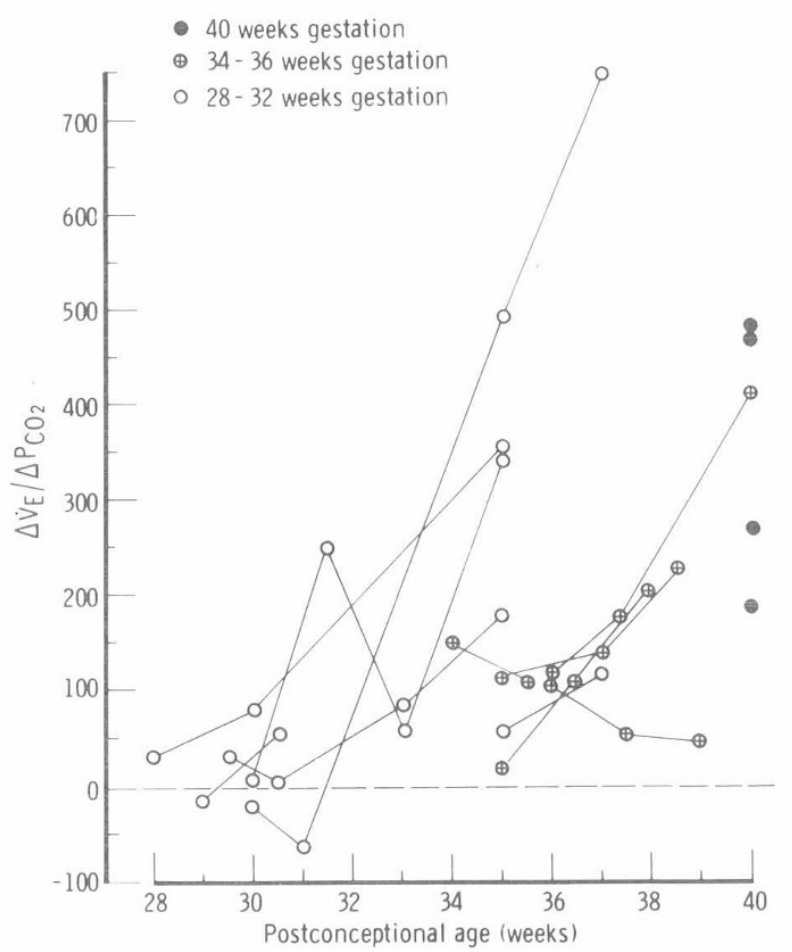

Fig. 3. Ventilatory response to carbon dioxide $\left(\Delta \dot{\mathrm{V}}_{\mathrm{E}} / \mathrm{P}_{\mathrm{CO}}\right)$ versus postconceptional age in weeks in infants of differing maturity.

Thirteen of the 16 infants studied had determinations of blood gases; all were within normal limits at the time of study.

Infants $2-5$ and 10 were found to have essentially no increase in minute volume in response to increased $\mathrm{CO}_{2}$ during the first week of life, as indicated by a reduced slope $\left(\Delta \dot{\mathrm{V}}_{\mathrm{E}} / \mathrm{P}_{\mathrm{CO}_{2}}\right)$. In three of these cases $(2,4$, and 5$)$, tidal volume did not increase in response to increased $\mathrm{CO}_{2}$. Tidal volume fell in cases 5 and 10. Case 3 showed a fall in respiratory rate, which is reflected in a reduced $\dot{V}_{\mathrm{E}}$. 
Table 2. $\mathrm{CO}_{2}$ sensitivity versus postconceptional age in weeks ${ }^{1}$

\begin{tabular}{|c|c|c|c|c|c|c|c|c|c|c|c|c|}
\hline \multirow[b]{2}{*}{$\begin{array}{l}\text { Postconcep- } \\
\text { tional age, wk }\end{array}$} & \multicolumn{4}{|c|}{ Unsized } & \multicolumn{4}{|c|}{ Sized by body wt, $\mathrm{kg}$} & \multicolumn{4}{|c|}{ Sized by FRC, cc } \\
\hline & $\begin{array}{c}\text { Mean } \Delta \dot{\mathrm{V}}_{\mathrm{E}} / \mathrm{P}_{\mathrm{CO}_{2}} \\
\mathrm{ml} / \mathrm{min} / \mathrm{mm} \mathrm{Hg}\end{array}$ & SD & SE & $P$ & $\begin{array}{c}\text { Mean } \Delta \dot{\mathrm{V}}_{\mathrm{E}} / \\
\mathrm{kg} / \mathrm{P}_{\mathrm{CO}_{2}} \\
{[(\mathrm{ml} / \mathrm{min}) / \mathrm{kg}] /} \\
\mathrm{mm} \mathrm{Hg}\end{array}$ & $\mathrm{SD}$ & SE & $P$ & $\begin{array}{c}\text { Mean } \Delta \dot{\mathrm{V}}_{\mathrm{E}} / \\
\mathrm{FRC} / \mathrm{P}_{\mathrm{CO}_{2}} \\
{[(\mathrm{ml} / \mathrm{min}) / \mathrm{cc}] /} \\
\mathrm{mm} \mathrm{Hg}\end{array}$ & SD & $\mathrm{SE}$ & $P$ \\
\hline $\begin{array}{c}<33 \text { wks } \\
n=13\end{array}$ & 44 & 79 & & $<0.01$ & 22 & 40 & $\left.{ }^{12}\right\}$ & $<0.01$ & 1.3 & 2.0 & $\left.{ }^{0.6}\right\}$ & \\
\hline $\begin{array}{c}33-36 \text { wks } \\
n=13\end{array}$ & 174 & 138 & $38 ?$ & $\begin{array}{l}<0.001 \\
<0.01\end{array}$ & 106 & 96 & $27\}$ & $\left\{\begin{array}{l}<0.001 \\
<0.60\end{array}\right.$ & 3.4 & 2.6 & $0.7\}$ & $\begin{array}{l}<0.05 \\
<0.01\end{array}$ \\
\hline $\begin{array}{c}37-40 \text { wks } \\
n=13\end{array}$ & 292 & 201 & $55)$ & & 127 & 90 & 251 & & 4.0 & 2.6 & $0.7)$ & $<0.5$ \\
\hline
\end{tabular}

${ }^{1}$ FRC: functional residual capacity.

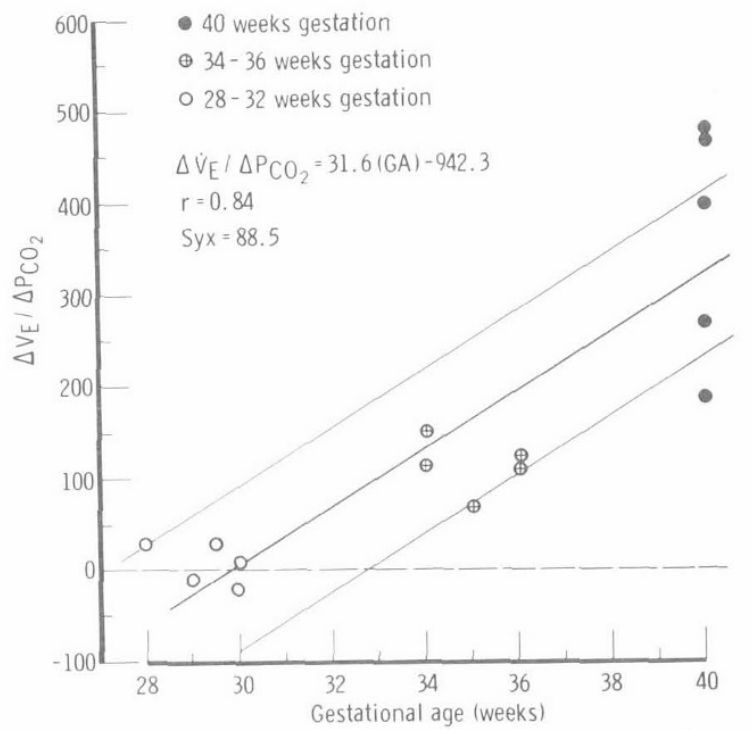

Fig. 4. Ventilatory response to carbon dioxide $\left(\Delta \dot{\mathrm{V}}_{\mathrm{E}} / \mathrm{P}_{\mathrm{CO}_{2}}\right)$ measured during the first week after birth in infants of 28-32 weeks, $34-36$ weeks, and 40 weeks of gestational age.

\section{DISCUSSION}

The present study demonstrates that premature infants of less than 33 weeks' gestational age have reduced ventilatory response to inspired carbon dioxide. Sensitivity to inspired $\mathrm{CO}_{2}$ appears to increase as 40 weeks' postconceptional age is approached. This effect appears to be strongly related to postconceptional age, since more mature infants have a higher $\mathrm{CO}_{2}$ response even during the first week of life.

Less mature infants tend to have smaller lung volumes and lower body weights than more mature infants. When changes in minute volume per millimeter of $\mathrm{CO}_{2}$ are expressed in terms of body size (length, weight, or lung volume), less mature infants still exhibit a diminished response to carbon dioxide when compared with term infants. Therefore, data from this study indicate a maturational effect independent of body size alone.

Although $\mathrm{CO}_{2}$ sensitivity correlates well with pulmonary compliance $(r=0.6)$, the effects of increased pulmonary compliance on $\mathrm{CO}_{2}$ response cannot be separated from those of age alone. Pulmonary compliance increases with postconceptional and postnatal ages. Thus, the roles of pulmonary and neurologic maturity cannot be separated in this study.

A significant finding was the failure of some infants to increase either tidal volume or respiratory rate during $\mathrm{CO}_{2}$ rebreathing. It has been suggested that the $\mathrm{CO}_{2}$ response of an individual is related to the ability to perform increased pulmonary work $(5,10)$. The data obtained in this study of premature infants suggest that the infants who appear to be unresponsive to $\mathrm{CO}_{2}$ are either (1) performing respiratory work at the maximum rate possible or (2) truly lack reflexes for $\mathrm{CO}_{2}$ sensitivity. Since chemoreceptors for oxygen appear

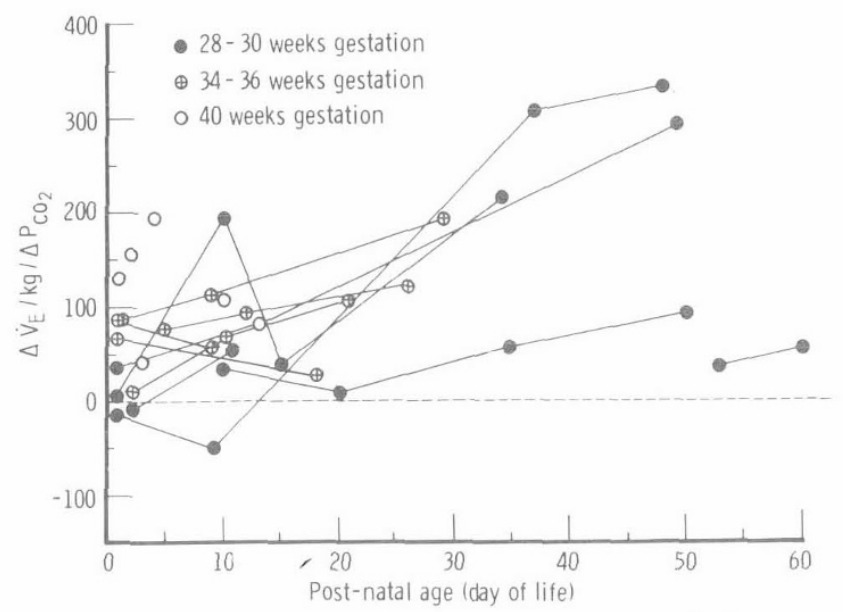

Fig. 5. Ventilatory response to carbon dioxide $\left(\Delta \dot{V}_{E} / P_{C O_{2}}\right)$ per kilogram of body weight versus postnatal age in days.

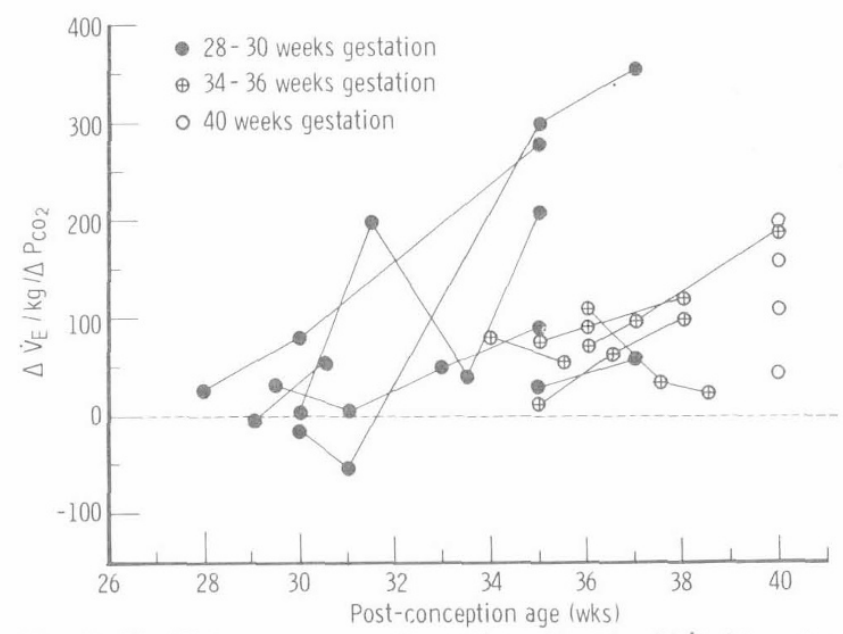

Fig. 6. Ventilatory response to carbon dioxide $\left(\Delta \dot{V}_{\mathrm{E}} / \mathrm{P}_{\mathrm{CO}_{2}}\right)$ per kilogram of body weight versus postconceptual age in weeks. 


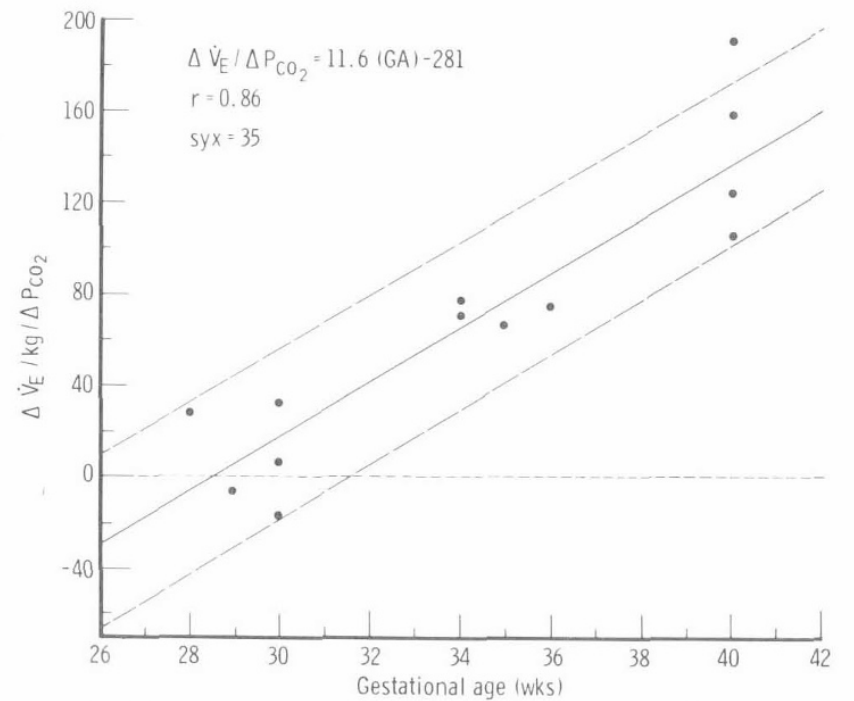

Fig. 7. Ventilatory response to carbon dioxide $\left(\Delta \dot{\mathrm{V}}_{\mathrm{E}} / \mathrm{P}_{\mathrm{CO}_{2}}\right)$ per kilogram of body weight during the first week of life in infants of $28-32$ weeks, $34-36$ weeks, and 40 weeks of gestational age.

Table 3. Response to $\mathrm{CO}_{2}{ }^{1}$

\begin{tabular}{lll}
\hline \multicolumn{1}{c}{$\Delta \mathrm{V}_{\mathrm{E}} / \Delta \mathrm{P}_{\mathrm{CO}}$ with } & \multicolumn{1}{c}{$\mathrm{r}$} & $P$ \\
\hline Gestational age & 0.84 & $<0.001$ \\
Compliance & 0.6 & $<0.001$ \\
Postconceptional age & 0.55 & $<0.001$ \\
FRC (total) & 0.5 & $<0.005$ \\
Body weight $(\mathrm{kg})$ & 0.5 & $<0.005$ \\
Body length $(\mathrm{cm})$ & 0.47 & $<0.01$ \\
Postnatal age & 0.37 & $<0.05$ \\
Total pulmonary resistance & 0.37 & $<0.05$ \\
Specific compliance & 0.005 & \\
\hline
\end{tabular}

${ }^{1}$ FRC: functional residual capacity.

to be present in the most immature infants $(8,12)$, one might reason that nonresponsive infants lack the ability to increase their pulmonary work. This matter awaits further investigation.

\section{SUMMARY}

Premature infants were found to have a reduced sensitivity to carbon dioxide when compared with term infants.
Sensitivity increased with postnatal age, body size, lung volume, and pulmonary compliance. Reduced sensitivity remained when all infants were compared on a weight or lung volume basis. This suggests a maturational effect unrelated to body size.

\section{REFERENCES AND NOTES}

1. Avery, M. E., Chernick, V., Dutton, R. E., and Permutt, S.: Ventilatory response to inspired carbon dioxide in infants and adults. J. Appl. Physiol., 18: 895 (1963).

2. Chernick, V., and Avery, M. E.: Response of premature infants with periodic breathing to ventilatory stimuli. J. Appl. Physiol., 21: 434 (1966).

3. Cook, C. D., Sutherland, J. M., Segal, S., Cherry, R. B., Mead, J., McIlroy, M. B., and Smith, C. A.: Studies of respiratory physiology in the newborn infant. III. Measurements of mechanics of respiration. J. Clin. Invest., 36: 440 (1957).

4. Cross, K. W., Hooper, J. D. M., and Oppe, T. E.: The effect of inhalation of carbon dioxide in air on the respiration of the full-term and premature infant. J. Physiol., 122: 264 (1953).

5. King, T. K. C., and Yu, D.: Factors determining the ventilatory response to carbon dioxide in chronic obstructive airways disease. Clin. Sci., 39: 653 (1970).

6. Krauss, A. N., and Auld, P. A. M.: Measurement of functional residual capacity in distressed neonates by helium rebreathing. J. Pediat., 77: 228 (1970).

7. Krauss, A. N., Thibeault, D. W., and Auld, P. A. M.: Acid-base balance in cerebrospinal fluid of newborn infants. Biol. Neonate, 21: 25 (1972).

8. Krauss, A. N., Tori, C. A., Brown, J., Soodalter, J., and Auld, P. A. M.: Oxygen chemoreceptors in low birth weight infants. Pediat. Res., 7: 569 (1973).

9. Miller, H. C., Behrle, F. C., and Smull, N. W.: Apnea and irregular respiratory rhythms among premature infants. Pediatrics, 23: 676 (1959).

10. Patton, J. M. S., and Freedman, S.: The ventilatory response to $\mathrm{CO}_{2}$ of patients with diffuse pulmonary infiltrations or fibrosis. Clin. Sci., 43: 55 (1972).

11. Read, D. J. C.: A clinical method for assessing the ventilatory response to carbon dioxide. Aust. Ann. Med. 16: 20 (1967).

12. Reinstorff, D., and Fenner, A.: Ventilatory response to hypoxia in premature and newborn infants during the first 3 days of life. Resp. Physiol., 15: 159 (1972).

13. Stahlman, M.: Ventilation control in the newborn. Amer. J. Dis. Child., 101: 216 (1961).

14. Hewlett-Packard Co., Avondale, $\mathrm{Pa}$.

15. Beckman Instruments, Palo Alto, Calif.

16. Dr. A. N. Krauss is recipient of a fellowship from the Tuberculosis and Respiratory Disease Association of New York and a travelling fellowship, Royal Society of Medicine Foundation.

17. Dr. P. A. M. Auld was supported by United States Public Health Service Research Grant no. HD-02644.

18. Requests for reprints should be addressed to: P. A. M. Auld, M.D., Division of Newborn Medicine, Department of Pediatrics, New York Hospital, Cornell University Medical Center, 525 E. 68th St., New York, N. Y. 10021 (USA).

19. Accepted for publication July 31,1974 . 